\title{
WEED TECHNOLOBY
}

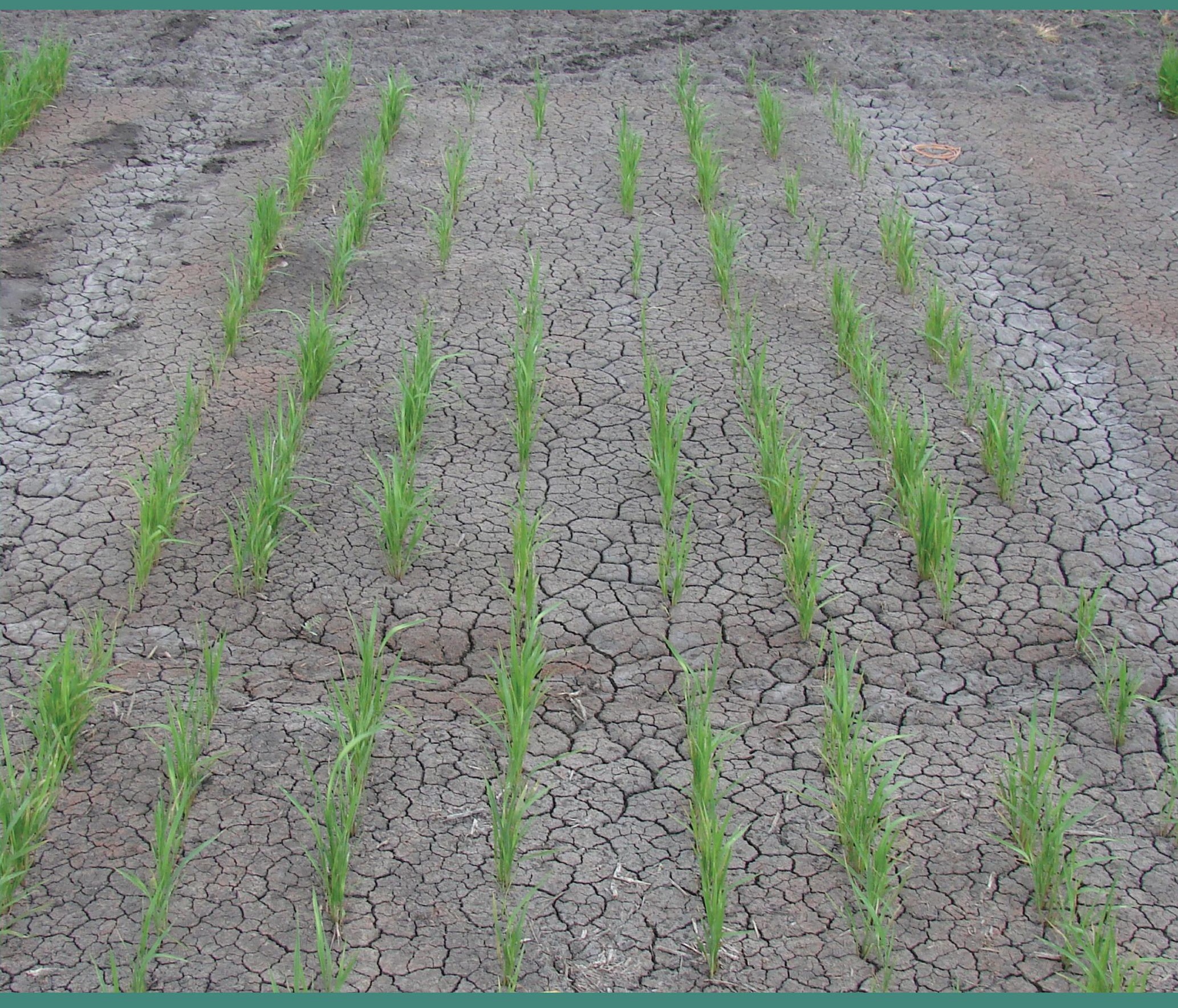




\section{Published six times a year by the Weed Science Society of America}

Jason K. Norsworthy, Editor

The Weed Science Society of America publishes original research and scholarship in the form of peer-reviewed articles in three international journals. Weed Science is focused on understanding "why" phenomena occur in agricultural crops. As such, it focuses on fundamental research directly related to all aspects of weed science in agricultural systems. Weed Technology focuses on understanding "how" weeds are managed. As such, it is focused on more applied aspects concerning the management of weeds in agricultural systems. Invasive Plant Science and Management is a broad-based journal that focuses not only on fundamental and applied research on invasive plant biology, ecology, management, and restoration of invaded non-crop areas, but also on the many other aspects relevant to invasive species, including educational activities, policy issues, and case study reports. Topics for Weed Technology include all aspects of weed management in agricultural, horticultural, ornamental, forestry, aquatic, turf, recreational, rights-of-ways, and other settings; weed resistance to herbicides; herbicide resistant crops; biological weed control agents; new weed management techniques; impacts of weed competition with crops; vegetation management with plant growth regulators; weed surveys; weed-related grower surveys; education; and extension. Symposia papers and reviews are accepted. Consult the editor for additional information.

\section{Associate Editors (Assignment Year)}

Jason Bond, Stoneville, MS (2010)

Kevin Bradley, Columbia, MO (2012)

Barry Brecke, Jay, FL (2013)

Ian Burke, Pullman, WA (2007)

Peter Dittmar, Gainesville, FL (2016)

Steve Fennimore, Salinas, CA (2004)

Aaron Hager, Urbana, IL (2012)
Brad Hanson, Davis, CA (2013)

Prashant Jha, Huntley, MT (2016)

Amit Jhala, Lincoln, NE (2018)

William Johnson, West Lafayette, IN (2007)

Andrew Kniss, Laramie, WY (2016)

Drew Lyon, Pullman, WA (2018)

Patrick McCullough, Griffin, GA (2016)

Scott McElroy, Auburn, AL (2012)
Robert Nurse, Guelph, ON (2016)

Darren Robinson, Ridgetown, ON (2008)

Larry Steckel, Jackson, TN (2007)

Daniel Stephenson, Alexandria, LA (2013)

Mark VanGessel, Georgetown, DE (2013)

Michael Walsh, Crawley, Australia (2016)

Eric Webster, Baton Rouge, LA (2018)

Cammy Willett, Fayetteville, AR (2017)

Tracy Candelaria, Managing Editor

\section{Officers of the Weed Science Society of America}

http://wssa.net/society/bod/

Weed Technology (ISSN 0890-037X) is published by the Weed Science Society of America, 12011 Tejon Street, Suite 700, Westminster, CO 80234. It is published bimonthly, one volume per year, six issues per year beginning in February.

Membership includes online access to Weed Technology, Weed Science, Invasive Plant Science and Management, and the online WSSA Newsletter. Dues should be sent to WSSA, 12011 Tejon Street, Suite 700, Westminster, CO 80234 no later than December 1 of each year. Membership in the society is on a calendar-year basis only.

New subscriptions and renewals begin with the first issue of the current volume. Please visit the Weed Technology subscription page at https://www.cambridge.org/core/journals/weed-technology/subscribe; Email: subscriptions_newyork@cambridge.org in USA, journals@cambridge.org outside USA.

Weed Technology publishes six times a year in February, April, June, August, October, and December. Annual institutional electronic subscription rates: US \$369.00; UK £257.00.

Please use Editorial Manager to access manuscript submissions (http://www.editorialmanager.com/wt). Authors are asked to pay $\$ 85$ for the first page and $\$ 65$ per page thereafter as a portion of the cost of publication, plus an additional processing charge of $\$ 55$ per manuscript if none of the authors are WSSA members. The Editor can make exceptions in advance when justified.

The Weed Science Society of America fully subscribes to the belief that progress in science depends upon the sharing of ideas, information, and materials among qualified investigators. Authors of papers published in Weed Technology are therefore encouraged, whenever practicable and when state and federal laws permit, to share genotypically unique propagative materials they might possess with other workers in that area who request such materials for the purpose of scientific research.

Weed Technology published by the Weed Science Society of America.

Copyright 2018 by the Weed Science Society of America.

All rights reserved. Reproduction in part or whole prohibited.

\section{Cover}

Center of photo depicts injury to spring planted rice mainly in the form of stand loss following pyroxasulfone at $170 \mathrm{~g}$ ai ha- 1 applied the previous fall. Note the healthy rice on each side of the center plot where pyroxasulfone was not applied. Photo courtesy of Dr. Jason Bond. 


\section{- RESEARCH ARTICLES}

Soybean Response to Dicamba: A Meta-Analysis. Andrew R. Kniss . . . . . . . . . . . . . . . . . . . . . 507

Response of Non-Dicamba-Resistant Soybean to Dicamba As Influenced by Growth Stage and Herbicide Rate.

Spencer McCown, Tom Barber and Jason K. Norsworthy $\ldots \ldots \ldots \ldots \ldots \ldots$

Insecticide Seed Treatments Partially Safen Rice to Low Rates of Glyphosate and Imazethapyr.

Steven M. Martin, Jason K. Norsworthy, Robert C. Scott, Jarrod Hardke, Gus M. Lorenz and Ed Gbur . . . . . . . . . 520

Effect of Fall-Applied Residual Herbicides on Rice Growth and Yield. Benjamin H. Lawrence, Jason A. Bond,

Henry M. Edwards, Bobby R. Golden, Garret B. Montgomery, Thomas W. Eubank III and Timothy W. Walker . . . . . . 526

Impact of Nealley's Sprangletop on Rough Rice Yield. Eric P. Webster, Eric A. Bergeron, David C. Blouin,

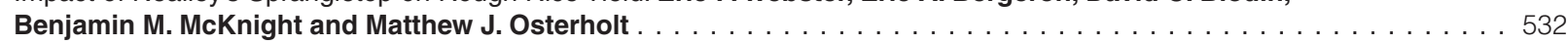

Weed Control and Selectivity of Pethoxamid Alone and in Mixture as a Delayed Preemergence Application to Rice.

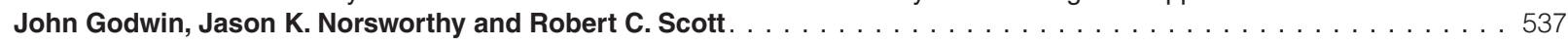

Evaluation of Pethoxamid-Containing Weed Control Programs in Drill-seeded Rice (Oryza sativa L.).

John Godwin, Jason K. Norsworthy and Robert C. Scott. . . . . . . . . . . . . . . . . . . . . . . . . 544

Field Measurements of Drift of Conventional and Drift Control Formulations of 2,4-D Plus Glyphosate. Patrick L. Havens,

David E. Hillger, Andrew J. Hewitt, Greg R. Kruger, Lia Marchi-Werle and Zbigniew Czaczyk. . . . . . . . . . . . . . 550

Nonionic Surfactant Affects Dislodgeable 2,4-D Foliar Residue from Turfgrass. Patrick J. Maxwell,

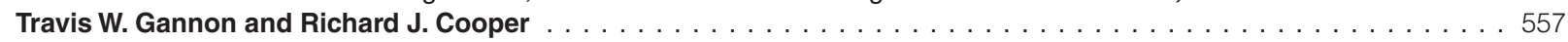

Seed treatments alleviate dormancy of field bindweed (Convolvulus arvensis L.). Renci Xiong, Ying Wang,

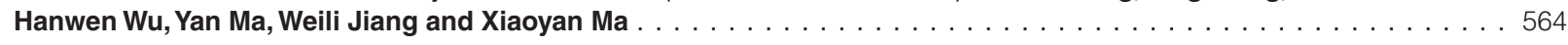

Investigations of the Potential Interactions Between Pre-emergence Residual Herbicides, Variety, and Seed Treatments in

Soybean. Blake R. Barlow, Lovreet S. Shergill, Mandy D. Bish and Kevin W. Bradley . . . . . . . . . . . . . 570

Differential Response of Arkansas Palmer Amaranth (Amaranthus palmeri) to Glyphosate and Mesotrione.

Shilpa Singh, Nilda Roma-Burgos, Vijay Singh, Ed Allan L. Alcober, Reiofeli Salas-Perez and Vinod Shivrain . . . . . . 579

Critical Period for Palmer Amaranth (Amaranthus palmeri) Control in Pickling Cucumber. Samuel J. McGowen,

Katherine M. Jennings, Sushila Chaudhari, David W. Monks, Jonathan R. Schultheis and Chris Reberg-Horton . . . . 586

Distribution of PPX2 Mutations Conferring PPO-Inhibitor Resistance in Palmer Amaranth Populations of Tennessee.

J. Drake Copeland, Darci A. Giacomini, Patrick J. Tranel, Garret B. Montgomery and Lawrence E. Steckel

\section{- WEED MANAGEMENT-MAJOR CROPS}

Weed Control with Halauxifen-Methyl Applied Alone and in Mixtures with 2,4-D, Dicamba, and Glyphosate.

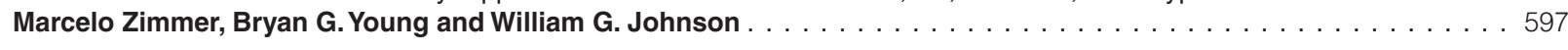

Activity of Florpyrauxifen-benzyl on Fall Panicum (Panicum dichotomiflorum Michx.) and Nealley's Sprangletop (Leptochloa nealleyi Vasey). Gustavo M. Teló, Eric P. Webster, Benjamin M. McKnight, David C. Blouin

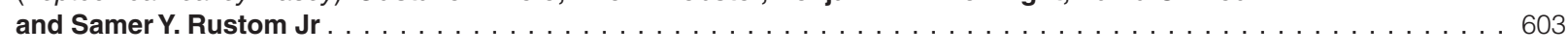

Injury Criteria Associated with Soybean Exposure to Dicamba. Matthew R. Foster and James L. Griffin . . . . . . . . . 608

\section{- WEED MANAGEMENT-OTHER CROPS/AREAS}

Walnut Response to Multiple Exposures to Simulated Drift of Bispyribac-Sodium. Mariano F. Galla,

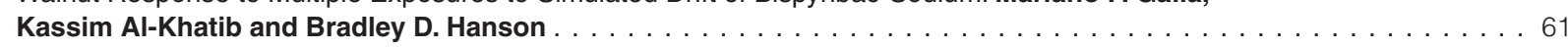

Effects of Integrated Polyethylene and Cover Crop Mulch, Conservation Tillage, and Herbicide Application on Weed Control, Yield, and Economic Returns in Watermelon. Andrew J. Price, Jacob P. Williams, Leah A. Duzy, J. Scott McElroy, Elizabeth A. Guertal and Steve Li.

Alternative Vine Management Programs for Fresh-Market Potatoes. Matthew J. Lemke, Jed B. Colquhoun, Daniel J. Heider and Richard A. Rittmeyer. 


\section{- EDUCATION/EXTENSION}

A Statewide Survey of Stakeholders to Assess the Problem Weeds and Weed Management Practices in Nebraska.

Debalin Sarangi and Amit J. Jhala . .

\section{- ERRATUM/CORRIGENDUM}

Injury Criteria Associated with Soybean Exposure to Dicamba - CORRIGENDUM. Matthew R. Foster and

James L. Griffin 